\title{
CORRELATION OF TOTAL IgE LEVEL AND INTENSITY OF INFECTION AMONG SOIL TRANSMITTED HELMINTHIASIS FARMERS IN KLUNGKUNG REGENCY, BALI, INDONESIA
}

\author{
Putu Indah Budi Apsari ${ }^{1}$, Heny Arwati², Yoes Prijatna Dachlan ${ }^{3}$ \\ ${ }^{1}$ Master Program of Basic Medical Science, ${ }^{2}$ Department of Parasitology, ${ }^{3}$ Department of Immunology, Faculty of \\ Medicine, Universitas Airlangga, Surabaya, Indonesia
}

\section{ABSTRACT}

\begin{abstract}
The phenomena of increasing total IgE level in Soil Transmitted Helminthiasis and its protective role in resistance of infection remains unclear. The purpose of this study was to determine the correlation between total IgE and the intensity of Soil transmitted helminthiasis among farmers in these area. Total 162 farmer, age ranged 25-80 years participated in this cross sectional analytic study. Kato-Katz method was used to diagnose Soil Transmitted Helminthiasis and to determined infection intensity based on egg per gram (EPG). Total IgE levels were measured by enzyme linked flourescent assay (ELFA). The results of this study showed that 13,56\% farmer positive for Soil Transmitted Helminthiasis, with single infection of Ascaris lumbricoides were 1,85\%, 9,26\% for Trichuris trichiura, 0,61\% for Hookworm and mixed infection that were 1,23\% for A.lumbricoides + T.trichiura $0,61 \%$ for A.lumbricoides + Hookworm. The intensity of infection were in mild category. Total IgE level in Soil transmitted Helminthiasis group was significantly different compared with noninfected group $(p<0.05, t$-test). There was significant correlation between EPG and total IgE level ( $r=0.667, p=0.001$, Spearman test). As a conclusion total IgE level was significantly correlated with EPG, this fact can be used to develop management of Soil Transmitted Helminthiasis theraphy.
\end{abstract}

Keywords: Farmers; soil transmitted helminthiasis; total IgE level; EPG; Klungkung; Bali

\section{ABSTRAK}

Fenomena peningkatan kadar IgE total pada infeksi Soil Transmitted Helminths (STHs) dan efek perlindungannya terhadap infeksi STHs belum jelas. Tujuan penelitian ini adalah untuk mengetahui hubungan antara kadar IgE total dengan intensitas infeksi STHs di Kabupaten Klungkung, Bali. Total 162 petani dengan usia 25-80 tahun berpartisipasi dalam penelitian cross sectional analitik ini. Metode Kato-Katz digunakan untuk mendiagnosis Soil Transmitted Helminthiasis dan menentukan intensitas infeksi berdasarkan egg per gram (EPG). Kadar IgE total diukur menggunakan enzyme linked flourescent assay (ELFA). Hasil penelitian menunjukkan bahwa 13,56\% petani menderita Soil Transmitted Helminthiasis, dengan infeksi tunggal Ascaris lumbricoides 1,85\% , Trichuris trichiura 9,26\%, Hookworm 0,61\%, sedangkan infeksi campuran A. lumbricoides + T. trichiura 1,23\% dan A.lumbricoides + Hookworm 0,61\%. Intensitas infeksi pada semua penderita dikategorikan ringan. Hasil penelitian menunjukkan kadar IgE total pada kelompok penderita Soil Transmitted Helminthiasis berbeda signifikan dibandingkan dengan kelompok bukan penderita Soil Transmitted Helminthiasis ( $p<0.05$, $t$-test). Kadar IgE total signifikan berhubungan dengan EPG $(r=0,667, p=0.001$, Spearman test). Sebagai kesimpulan terdapat hubungan antara kadar IgE total dengan intensitas infeksi Soil Transmitted Helminthiasis, sehingga dapat digunakan untuk pengembangan manajemen terapi.

Kata kunci: Petani; soil transmitted helminthiasis; kadar IgE total, EPG; Klungkung; Bali

Correspondence: Putu Indah Budi Apsari, Dusun Meranggen Desa Tangkas, Klungkung, Bali, Indonesia. Phone: +6282236602539/+6281933100298. Email: putuindah51@yahoo.com

pISSN:2355-8393 • eISSN: 2599-056x • doi: http://dx.doi.org/10.20473/fmi.v55i2.14333

- Fol Med Indones. 2019;55:93-99 • Received 14 Mar 2018 • Accepted 20 Sep 2018

- Open access under CC-BY-NC-SA license • Available at https://e-journal.unair.ac.id/FMI/

\section{INTRODUCTION}

The soil-transmitted helminths are group of parasitic nematode worms causing human infection through contact with parasite eggs or larvae. They grown in the warm and moist soil of the world's tropical and subtropical countries (Bethony et al, 2006). More than 1,5 billion population in the world infected by STH. Of particular worldwide importance are the roundworms (Ascaris lumbricoides), whipworms (Trichuris trichiura), and Hookworms (Necator americanus and Ancylostoma duodenale) (WHO, 2017). Population at risk are childreen, farmer, gardener and tea picker. In Kediri region, Indonesia Elfred et al (2016) reported prevalence of A. lumbricoides infection among farmer were $40 \%$, T.trichiura and Hookworm were $0,025 \%$ 
each. In Bali, based on research conducted at Udayana University's Parasitology Laboratory during 2004-2011, stated that the prevalence of STH infection in rural population in Bali is relatively high, $74 \%$ for A.lumbricoides, $63 \%$ for T. trichiura, and $35 \%$ for Hokworm. In 2004 other studies conducted at 37 primary schools in Singaraja, Badung, Denpasar, Klungkung, Gianyar and Bangli areas, showed an average prevalence of STH infection of $58.3 \%-96.8 \%$ (Sudarmaja, 2011). STH infection are related to poverity, low social economic status and dereased of productivity and imbalance of immunity respon with Malaria, HIV/AIDS, TBC and respon to vaccine (WHO, 2017).

Immunological respon to STH infection are $\mathrm{IgE}$, eosinophil, mast cell, and basophil. IgE activate mast cell through FceRI, stimulate mediators release that influence gut mechanism to weep and sweep worm from the gut. Efector cell reqruitment such as Th2, eosinophil and macrofag are mediated by cytokines, then localised in infected cell and kill the parasite (Cooper, 2009). IgE level are concomitant with the number of worm in the gut but this mechanism still unclear. In chronic infection, B cell switch class to produced IgG4 so that IgE level decrease. In acute infection eosinophil count higher than chronic infection. By measuring IgE level, and intensity of infection, we can evaluate effect of STH infection for $\operatorname{IgE}$ level and their protective role in immunity system to helminth infection (Acevedo et al, 2011).

The general objective of this study was to analyze the correlation of IgE level with the intensity of infection (EPG) among STH infected farmers in Klungkung, Bali. The results of this study can be used to develop management therapy of STH infection and suggest the government to cure and to do preventive program for uninfected farmer.

\section{MATERIALS AND METHODS}

\section{Study area}

This research was conducted in Gelgel village, Klungkung regency, Bali, Indonesia. This study was conducted in from December 2017 to January 2018. The design of the study was a descriptive analitical research and implemented with the Cross sectional design. Fecal samples were analyze in Parasitology laboratorium, Universitas Udayana. IgE level are measured in Clinical Pathology laboratorium, Sanglah Central Hospital.
Data were collected from adult farmer in Gelgel village, Klungkung regency, Bali, Indonesia. Total 250 farmer in Gelgel village were selected by simple randome sampling, only 210 sample fill the inclusion criteria. Forthy sample are exclude because of illness such as Diabetes mellitus, Tuberculosis, Stroke. Total 162 sample returned complete quitionaire and fecal samples.

\section{Ethical consideration}

Ethical certificate no.294/EC/KEPK/FKUA/2017 was obtained from Ethical Department Faculty of Medicine, Universitas Airlangga, Surabaya.

\section{Samples collection}

Two days before collection of samples, total 210 quitionaire and fecal container was given to subject. Informed consent was given before interview then researcher filled the quitionaire by asking subject directly. Fecal container then given to subject, and will be collected tomorrow morning. Fecal samples then preserved by formaline $10 \%$ and examined by KatoKatz technique using malachite green smear to identify egg morphology of each species and to count egg per gram (EPG) feces (WHO 2017). The number of positif egg will be multiplicated by 24 . Blood sample were then taken from infected and uninfected serum to obtain serum prior to total IgE level measurement. Blood sampel obtain from cubital vein were collected in $3 \mathrm{ml}$ each tube EDTA and serum separator and clot activator (BD Vacutainer, NJ, USA). Tube were centrifuged within 15 minutes $30.000 \mathrm{rpm}$ and serum was stored in ?40oC until immunological analysis. Hematological automated analyses were performed within 4 hours of sample collection and were done by flowcytometry method (Cell Dyn Ruby Abbott, USA). IgE tests were performed used ELFA method (Vidas Biomerieux, France) with insert kit total IgE Vidas according to the manufacturer's instructions. Normal total $\mathrm{IgE}$ value for adult $<100 \mathrm{IU} / \mathrm{mL}$.

\section{Data analysis}

All data were tested for normality with the Kolmogorov-Smirnov ( $>0.05)$ and tested of homogeneity with Levene test $(\mathrm{p}<0.05)$. Statistical analysis by independent $t-$ test $(p<0.05)$. Correlation test performed with Spearman's test $(\mathrm{p}<0.05)$ or Pearson test $(p<0.05)$. The effect of independent variabel to dependent variable were tested using linear regression test $(\mathrm{p}<0,05)$.

\section{RESULTS}


Total 162 fecal samples were collected from farmers, 22 fecal samples positive Soil Transmitted Helminthiasis and 140 sample negative for Soil Transmitted Helminthiasis. The prevalence of STH infection are $13,5 \%$. Most of them are male (54-64\%) with length of work about 20 years and duration of work about 9 hours. Most of subject pass elementary school and also cattle owner with low income under 250 thousand rupiahs. All data shown in Table 1.

\section{Species Distribution and EPG in positive group}

In the STH-positive group the highest number of species was $T$. trichiura counted in $15(9.26 \%)$ samples, followed by $A$. lumbricoides 3 (1.85\%) samples, Hookworm $1(0.61 \%)$ samples and and mixed infections respectively $2(1.23 \%)$ samples for Ascaris+ Trichuris, $1(0.61 \%)$ samples for Ascaris+Hookworm. The highest mean EPG was A. lumbricoides as many as 160 eggs per gram of feces, then Ascaris+Hookworm mixed infection of 144 eggs per gram of feces, Trichuris+Ascaris 132 eggs per gram of feces, while Hookworm and T. trichiura respectively as many as 48 and 53.5 eggs per gram of feces. Intensity of infection according to WHO table is entirely mild intensity all data shown in Table 2.

\section{Correlation of total IgE levels and EPG}

The total IgE level is normally distributed while the EPG is not normally distributed, so the Spearman correlation test is used to test the correlation between total IgE level and EPG. There was correlation of total IgE level and EPG $(r=0.667 \mathrm{p}=0.001)$. The correlation between total IgE and EPG was then analyzed using linear regression to determine the extent to which the EPG affected total IgE levels. The results are shown in Figure 2, with the equation $y=2,3 x+267$ $(\mathrm{p}=0.001)$.

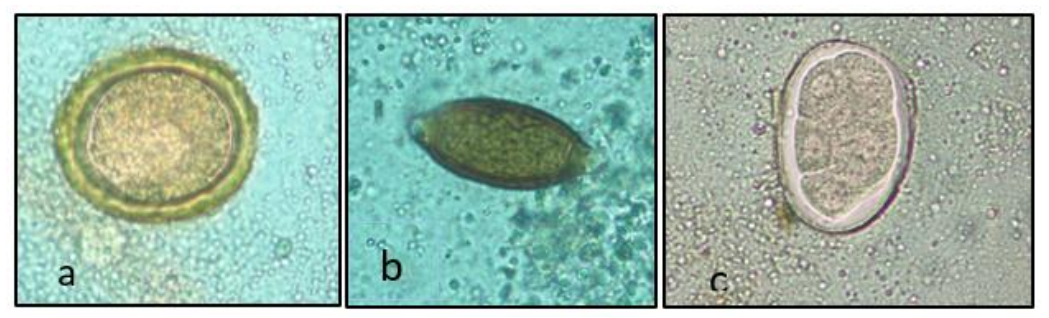

Fig. 1. Morphology of egg per species, identification by Kato-kats Thick smear using malachite green. Observation under light microscope 40x objective (Olympus, Tokyo, Japan) (a) A.lumbricoides fertilized egg, (b) $T$. trichiura egg (c) Hookworm egg.

Table 1. Characteristic of subject

\begin{tabular}{lcc}
\hline Characteristic of subject & STH Positive $\left(\mathrm{n}^{*}=22\right)$ & STH negative $(\mathrm{n}=140)$ \\
\hline Age (year); mean \pm SD* & $55.59 \pm 8.1$ & $55.11 \pm 10.9$ \\
Duration of work (year); mean \pm SD & $21.9 \pm 11.4$ & $20.7 \pm 13.8$ \\
Work hour (hour): mean \pm SD & $9.1 \pm 1.6$ & $8.6 \pm 1.7$ \\
Gender; $\mathrm{n}(\%)$ & & \\
$\quad$ Male & $12(54.5)$ & $90(64.3)$ \\
$\quad$ Female & $10(45.5)$ & $50(35.7)$ \\
Level of education; $\mathrm{n}(\%)$ & $9(40.9)$ & $39(27.9)$ \\
$\quad$ Not attending school & $9(40.9)$ & $70(50.0)$ \\
Elementary & $1(4.5)$ & $12(8.6)$ \\
Junior high & $3(13.6)$ & $18(12.9)$ \\
High & $0(0)$ & $1(0.7)$ \\
University & $12(54.5)$ & $72(51.4)$ \\
Salary per month; $\mathrm{n}(\%)$ & $10(45.5)$ & $62(44.3)$ \\
$\quad<250$ thousand & $0(0)$ & $6(4.3)$ \\
$500-<1$ milion & & \\
$>1$ milion & $17(77.3)$ & $117(83.6)$ \\
Cattle owner: $\mathrm{n}(\%)$ & $5(22.7)$ & $23(16.4)$ \\
Yes & & \\
No & &
\end{tabular}


Table 2. Species distribution, mean EPG and Intensity of STH infection

\begin{tabular}{lccc}
\hline Species & $\mathrm{n}(\%)$ & Mean \pm SD (EPG) & Intensity of infection \\
\hline A.lumbricoides & $3(1.85)$ & $160 \pm 176$ & Mild* \\
T. trichiura & $15(9.26)$ & $53.5 \pm 27.9$ & Mild \\
Hookworm & $1(0.61)$ & 48 & Mild \\
Ascaris + Trichuris & $2(1.23)$ & $132 \pm 118$ & Mild \\
Ascaris + Hookworm & $1(0.61)$ & 144 & Mild \\
*Category based on WHO (2017) & & &
\end{tabular}

Table 3. Difference of total IgE mean between group

\begin{tabular}{lccccc}
\hline & & & \multicolumn{2}{c}{$95 \%$ Confidence Interval } & \\
\cline { 4 - 5 } Species & $\mathrm{n}$ & Mean \pm SD $(\mathrm{IU} / \mathrm{mL})$ & Lower bound & Upper bound & $\mathrm{p}$ \\
\hline Uninfected & 20 & $250 \pm 217$ & 148 & 352 & 0.00 \\
A.lumbricoides & 3 & $994 \pm 916$ & 971 & 1017 & 0.00 \\
T. trichiura & 13 & $245 \pm 249$ & 94 & 396 & 0.95 \\
Hookworm & 1 & 683.81 & na & na & 0.06 \\
Ascaris + Trichuris & 2 & 1000 & -2781.06 & 4229.33 & 0.00 \\
Ascaris + Hookworm & 1 & 741.57 & na & na* & 0.04 \\
\hline
\end{tabular}

*Na: cannot been analyzed, level of significance, $\mathrm{p}<0.05$

Table 4. Mean difference of total IgE level each species

\begin{tabular}{lclcc}
\hline Species & Mean $\pm \mathrm{SD}(\mathrm{IU} / \mathrm{mL})$ & Species & Mean $\pm \mathrm{SD}(\mathrm{IU} / \mathrm{mL})$ & $\mathrm{p}$ \\
\hline A.lumbricoides & $994 \pm 916$ & T.trichiura & $245 \pm 249$ & 0.000 \\
A.lumbricoides & $994 \pm 916$ & Hookworm & 683.81 & 0.001 \\
A.lumbricoides & $994 \pm 916$ & A.lumbricoides + T.trichiura & 1000 & 0.495 \\
A.lumbricoides & $994 \pm 916$ & A.lumbricoides + Hookworm & 741.57 & 0.002 \\
T.trichiura & $245 \pm 249$ & Hookworm & 683.81 & 0.116 \\
T.trichiura & $245 \pm 249$ & A.lumbricoides + T.trichiura & 1000 & 0.001 \\
T.trichiura & $245 \pm 249$ & A.lumbricoides + Hookworm & 741.57 & 0.08 \\
Hookworm & 683.81 & A.lumbricoides T.trichiura & 1000 & na* \\
Hookworm & 683.81 & A.lumbricoides + Hookworm & 741.57 & na \\
\hline
\end{tabular}

*Na: cannot been analyzed, level of significance, $\mathrm{p}<0.05$

\section{The difference of mean of total IgE levels between infected and uninfected group}

The unpaired t-test showed that there was a significant difference of total $\mathrm{IgE}$ level mean between $A$. lumbricoides infected group and uninfected group $(\mathrm{p}=0,00)$, Ascaris+Hookworm with uninfected group $(\mathrm{p}=0.04)$ and Ascaris+Trichuris with uninfected $\operatorname{group}(\mathrm{p}=0.00)$, shown in Table 3 that mixed infection between Ascaris+Trichuris had higher mean total IgE levels $(1000 \mathrm{IU} / \mathrm{mL})$ than single infections of $T$. trichiura, A. lumbricoides and Hookworm.

\section{The mean difference of total IgE levels in each species}

The unpaired t-test of the difference in total $\operatorname{IgE}$ mean between species was found to be difference significantly in A. lumbricoides infection compared with T.trichiura infection $(\mathrm{p}=0.000), A$. lumbricoides compared with Hookworm ( $\mathrm{p}=0.001)$, A. lumbricoides compared with mixed infection Ascaris+Hookworm ( $\mathrm{p}=$ 0.002), Trichuris compared with mixed infection of Ascaris+ Trichuris $(\mathrm{p}=0.001)$. There was no difference of $\operatorname{IgE}$ total mean between Ascaris single infection with mixed infection of Ascaris + Trichuris $(p=0.495)$, Trichuris compared with Hookworm $(\mathrm{p}=0.116)$, Trichuris 
compared with Ascaris+Hookworm mixed infection $(p=0.08)$. The difference of mean of Hookworm with Ascaris+Trichuris mixed infection could not be analyzed because the amount of data was less than 3, so Hookworm with Ascaris + Hookworm mixed infection.

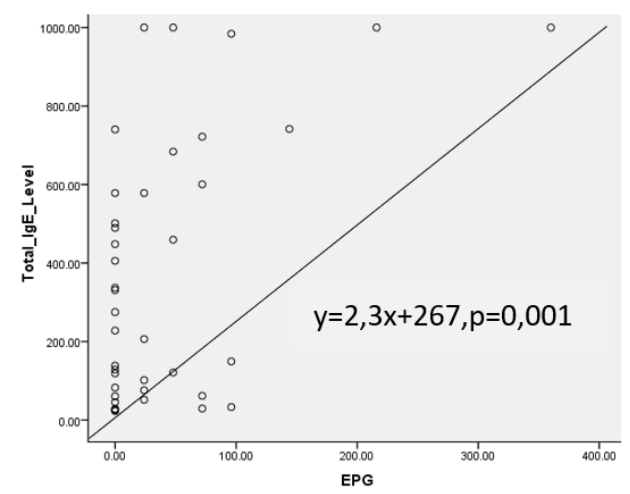

Fig. 2. Scatter plot correlation of total $\operatorname{IgE}$ level with EPG, tend to be positive correlation. Independent variable EPG can be used to predict value of total IgE level by using the equation above.

\section{DISCUSSION}

STH infection remains a major health problem in many poor and developing countries. Consistent with the findings of previous studies, this study shows that prevalence of STH infection among farmer are 13,5\% same with previous study by Amoah et al (2016). The similar result because subject of this research were vegetable farmer same with Amoah study. Most of farmer consume own vegetable product that increase risk of $\mathrm{STH}$ ova exposure $(\mathrm{OR}=1,25, \mathrm{CI} 95 \%)$. The prevalence of STH infection among adult also have been reported in Nyanza, Kenya, overall $15.7 \%$ adult positive for STH infection. The possibility for adult as carier of STH was evaluated by Bopda et al (2016) in Akonolinga, Cameroon, infected adult might constitute a potential parasite reservoir and a source of dissemination and persistence of STH infection.

The prevalence of A. lumbricoides infection in this study was $1,85 \%$, this result is in accordance with the study conducted by Ensink et al (2005), the prevalence of A. lumbricoides infection was $1.9 \%$. They also obtained Hookworm prevalence ranges from $0.6 \%$ in regular farmer similar with this study $(0.6 \%)$. The prevalence of $T$. trichiura infection in this study was $9.26 \%$, in a study conducted by Pham-duc et al (2013) the $T$. trichiura prevalence was $40 \%$, higher than this study. This is due to the geographical differences in the study area, the ability of each species of worm to live and infect and the susceptibility of each person to get infected with different worms in each region. This study obtained EPG ranging between 48-160, this result is in accordance with research conducted by Amoah et al (2016) with the average number of eggs per gram of feces in the rainy season 4-223 EPG and in dry season 3 -124 EPG. The similarity of the results obtained because the sample used has similarities with this study. The farmers of rice, vegetables and maize in Gelgel Village was similar with vegetable farmers subject in Kumasi, Ghana. Because of same pattern every day exposed to the soil, the risk of STH infection will be higher $(\mathrm{OR}=$ 3.99 , 95\% CI: 1, 15-13,86) among farmer than nonfarmer subject. Intensity of STH infection was entirely in the mild category according to Amoah et al (2016).

\section{Correlation between total IgE levels and EPG}

The positive correlation between total IgE level and EPG $(r=0.667 \mathrm{p}=0.001)$ in this study, same as the study in Honduras Gabrie, et al (2016). A positive correlation between EPG with total IgE levels was found in A. lumbricoides and T.trichiura. The amount of antigen presented by the high parasitic burden would be directly proportional to the number of antibodies formed by B cells (Gabrie et al 2016). The factor that affecting worm species induces antibody formation was determined by the immunogenicity of antigen presented, the number of antigens presented, the habitat of the worm (tissue worms would induced larger production of antibodies than intestinal worms), and host's immune response to the worms (Anthony et al., 2007). On the other hand, a study in children showed that there was no correlation between the intensity of infection with total IgE levels (Wijaya et al 2014).

\section{The mean difference of total IgE levels between infected and uninfected group}

Single infection of A. lumbricoides infection showed the highest total IgE levels compared with other single infections $($ mean $=994,95 \%$ CI 971-1017, $\mathrm{p}=0.00)$. The massive increase of $\mathrm{IgE}$ levels in A. lumbricoides infection is induced by the combination of mitogenic effects of B cells by Ascaris antigens such as ABA-1 proteine, and tropomyosin, and non-specific induction from the environment due to the secretion of IL-4 by Th2 cells (Cooper 2009).

The high prevalence of $T$. trichiura infection might be caused from, firstly there was no difference in total $\mathrm{IgE}$ levels compared with uninfected $(\mathrm{p}=0.95)$. This is probably due to the low amount of EPG resulting in low antigen production, and the host response to form a low antibody is ineffective in eliminating the parasite. Secondly, IgE blocking mechanism and decreased of 
host's immune system regulation in chronic worm infection. This can be explained by B cells decrease IgE production by switch class to produce IgA and IgG4. Treg cell balanced the immunopathogenicity by producing IL-10. Levels of IgG4 and IL-10 in this case also inhibits the hypersensitivity reaction, so that in chronic worm infection allergic events will go down (Smits, et al., 2010). Thirdly, life cycle of T.trichiura which was different from other STH species. In their life cycle T.trichiura does not pass through the blood circulation or the organs, so that the circulating antigen was limited in the intestinal lumen. Amount of antibodies specific to T.trichiura will also be smaller than other species (Anthony et al 2007). Antigen shading of T.trichiura can be one of escape mechanism from host's immune respons (Cooper 2008).

\section{The difference of mean of IgE total in each species}

Due to the life cycle, the fact that A. lumbricoides passed through multiple organ by invading blood circulation and spread their antigen excessively is not ony causing various clinical symptoms baut also increasing the amount antigen so that the level of antibody. Different with T.trichiura that only habitating intestinal lumen the amount of $\mathrm{IgE}$ produced might be lower than A. lumbricoides. Total IgE level in $A$. lumbricoides infection compared with Hookworm also significantly different $(\mathrm{p}=0.001)$. The size and fecundity of A. lumbricoides is bigger than Hookworm causing larger amount of eggs. The egg acts as antigen that increases level of IgE (Farrar et al 2014).

Total IgE levels in mixed infection of Ascaris+Trichuris (1000 IU/mL) was higher than single infections of, $A$. lumbricoides, T. trichiura or Hookworm. The amount of antigen produced is directly proportional to EPG and the combination of specific antigens produced by both species. Increasing IgE level in mixed infections was more predominantly than single infection (Geiger et al., 2010). The results of this study was accordance with previous research that conducted by Gabrie et al (2016), the highest mean of $\mathrm{IgE}$ was in mixed infections (mean $=1463.7 \mathrm{IU} / \mathrm{mL})$. Different results were showed by Wijaya et al (2016), there was no significant difference in mean total IgE levels in A. lumbricoides with mixed infection of $A$. lumbricoides $+T$. trichiura $(\mathrm{p}=0.38)$, but the highest total IgE level was in mixed infections of $A$. lumbricoides + T.trichiura (1.222.5 IU/mL) (Gabrie et al 2016).

It can be concluded that total IgE level in Soil Transmitted Helminthiasis was not capable in eliminating infection, and in cutting down the prevalence. So, antihelminth mass drugs admission is still needed.

\section{CONCLUSION}

STH infection by two species or more is likely to induce more production of antibody because of accumulation of antigens to stimulate the host's immune response. There are significant correlation of total IgE with EPG. The amount of EPG is propotionaly same as the amount antigen. Therefore the higher amount of antigen caused the higher amount of IgE. Future research must be conducted to obtain mechanism of EPG in influencing specific IgE production by B cells.

\section{REFERENCES}

Acevedo N, Erler A, Briza P (2011). Allergenicity of Ascaris lumbricoides tropomyosin and IgE sensitization among asthmatic patients in a tropical environment. Int Arch Allergy Immunol 154, 195-206

Amoah ID, Abubakari A, Stenstrom TA (2016). Contribution of wastewater irrigation to soil transmitted helminths infection among vegetable farmers in Kumasi, Ghana. PLOS Neglected Tropical Diseases 10, 1-12

Andereck JW, Kipp, Aaron M, Ondieck M, Vermund SH (2014). Helminth prevalence among adult in rural Kenya: a stool survey for soil-transmitted helminth and Schistosomiasis in Nyanza province. Transaction of the Royal Society of Tropical Medicine and Hygiene 108, 804-806

Anthony RM, Rutitzky LI, Urban JF (2007). Protective immune mechanisms in helminth infection. Nature Publishing Group 7, 975-987

Bethony J, Brooker S, Albonico M (2006). Soiltransmitted helminth infections: ascariasis, trichuriasis, and hookworm. Lancet 367, 1521-1532

Cooper PJ (2009). Interaction between helminth parasite and allergy. Curr Opin allergy Clin Immunol 9, 29-37

Cooper PJ, Ayre G, Martin C (2008). Geohelminth infections: a review of the role of $\operatorname{IgE}$ and assessment of potential risks of anti-IgE treatment. Allergy 63, 409-417

Elfred, Arwati H, Suwarno (2016). Gambaran basofil, TNF-a, dan IL-9 pada petani terinfeksi STH di kabupaten Kediri. Jurnal Biosains Pascasarjana 18, 113

Ensink JH, Hoek Wvd, Mukhtarb M (2005). High risk of Hookworm infection among wastewater farmers in Pakistan. Transactions of the Royal Society of Tropical Medicine and Hygiene 99, 809-811

Farrar J, Hotez PJ, Junghanss T (2014). Manson's Tropical Disease. 23rd ed. China, Elsevier

Gabrie JA, et al (2016). Immune profile of Honduran schoolchildren with intestinal parasites: The Skewed 
response against geohelminths. Journal of Parasitology Research, 1-13

Geiger SM, Alexander, NDE, Fujiwara RT, Brooker S (2011). Necator americanus and helminth coinfection: Further down-modulation of hookwormspecific type 1 immune responses. Plos Neglected Tropical Disease 5, 1-11

Pham-Duc P, Nguyen-Viet H, Hattendorf J (2013). Ascaris lumbricoides and Trichuris trichiura infections associated with wastewater and human excreta use in agriculture in Vietnam. Parasitology International 62, $172-180$

Smits HH, Everts B, Hartgers FC, Yazdanbakhsh M (2010). Chronic helminth infections protect against allergic diseases by active regulatory processes. Curr Allergy Asthma Rep 10, 3-12

Sudarmaja I (2011). Epidemologi infeksi kecacingan di Bali. Bali, Laboratorium Parasitologi, Universitas Udayana

WHO (1991). Basic laboratory method in medical parasitology. 1st Ed. Geneva, World Health Organzation

WHO (2017). World Health Organization. www.who.int/intestinal_worms. Accessed August 16, 2017

Wijaya H, Irsa L, Loebis S (2014). Total serum IgE levels in soil transmitted helminth infected children with atopy symptoms. Paediatrica Indonesiana 54, $149-153$ 